\title{
FROM FORMALISM TO FEMINISM SEVENTY-FIVE YEARS OF THEORY IN THE LEGAL ACADEMY
}

\author{
F.C. DeCOSTE
}

This article traces the origins of present legal theories and appraises their moral and ethical significance for legal education, scholarship and practice. The author begins by exploring how three related moments in law's intellectual past formalism, realism and accommodationism - are productive of the present legal theoretical landscape. Next he characterizes the intellectual and moral substance of the present which these moments have compelled. The conclusion of the article is devoted to the future promised, or perhaps threatened, by this present and this past.
Le présent article retrace les origines des théories juridiques actuelles et évalue leur importance morale et éthique pour l'éducation, la recherche et la pratique en matière de droit. L'auteur commence par examiner comment trois époques connexes de ce passé intellectuel - le formalisme, le réalisme et l'accommodationisme - ont déterminé le paysage théorique juridique d'aujourd'hui. Il caractérise ensuite la substance intellectuelle et morale de ce présent. La conclusion est consacrée à l'avenir prometteur ou menaçant que nous réservent ce présent et ce passé.

\section{TABLE OF CONTENTS}

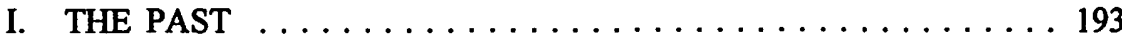

A. LAW AS AUTARKY: THE FORMALIST MOMENT . . . . 194

B. LAW AS FUNCTION: THE REALIST MOMENT . . . . . 199

C. LAW AS AUTARKY REDACTED:

THE ACCOMMODATIONIST MOMENT ........ 205

II. THE PRESENT $\ldots \ldots \ldots \ldots \ldots \ldots \ldots \ldots \ldots \ldots \ldots . \ldots \ldots$

III. A TENTATIVE CONCLUSION $\ldots \ldots \ldots \ldots \ldots \ldots \ldots \ldots 218$

[T] which can demonstrate the validity of any value judgement or the "ought" of any legal maxim. Those lawyers who have claimed such a role for themselves as legal people are in my eyes the most godforsaken bunch in the world. If there is anyone who is not suited to decide what ought or ought not to be, it is a lawyer, if he wishes to be a man of his science,

is duty-bound to be a formalist.

-Max Weber'

Law means so pitifully little to life. Life is so terrifyingly dependent on law.

-Karl N. Llewellyn ${ }^{2}$

Associate Professor, Faculty of Law, University of Alberta.

M. Weber, Gesammelte Aufsatze zur Soziologie und Sozialpolitik (Tubingen: Mohr, 1924) at 401. K.N. Llewellyn, "What Price Contract? - An Essay in Perspective" (1931) 40 Yale L.J. 704 at 751. 
Virtue in a republic is a most simple thing;

it is a love of the republic.

-Montesquieu ${ }^{3}$

In a 1954 report on the course of jurisprudence to mid-century, Lon L. Fuller describes a legal theoretical landscape fully colonized by the continuing contest between legal positivism and natural law. ${ }^{4}$ Mapping the same terrain some thirteen years later, Julius Stone discovers a typography similar to Fuller's in most respects save one: by 1967, Professor Stone reports, jurisprudence was beginning to reflect "crosscurrents of thought from many branches of philosophy and social and political sciences." ${ }^{\text {S }}$ By 1989, however, Professor Minda was able to report a geography fundamentally altered. Gone entirely are the legal positivists and the natural lawyers. Gone too is the need even to mention theoretic commerce between law and other disciplines. That cross-border traffic, rather, is simply everywhere displayed and presumed. What Minda does report is this: that by the 1980s, legal theory is a conversation fractured by political positions and characterized above all else by a failure of communication between what he terms "mainstream legal theorists" and "the new critics."

It is the burden of this short essay to account for the changes in legal understanding which in concert, these three reports serve to disclose. My intention is not - at least in any robust sense - to present an intellectual or social history of the past seventyfive years ${ }^{7}$ or, much less, to offer a theory about the evolution of legal theory during

3 C. de Secondat Montesquieu, The Spirit of the Laws, trans. A.M. Cohler, B.C. Miller \& H.S. Stone (Cambridge: Cambridge University Press, 1989) at Book V, 2.

4 L.L. Fuller, "American Legal Philosophy at Mid-Century" (1954) 6 J. Leg. Ed. 457. Incidentally, Fuller's essay is otherwise notable both for formulating an attitude towards positivism in terms of the experience of German fascism and for outlining what would later become his full-fledged, if modest, theory of secular natural law. That theory found its final expression in L.L. Fuller, The Morality of Law (New Haven: Yale University Press, 1964) [hereinafter The Morality of Law].

J. Stone, "Trends in Jurisprudence in the Second Half Century" in B.D. Hathaway, Julius Stone: A Bio-bibliography (Tarlion Law Library Legal Bibliography No. 20) (Austin: U. Texas Law School, 1980) 16 at 17. In this essay, Professor Stone displays a particularly clear-headed sensibility towards the future which we now inhabit. After identifying "the flight from belief in universalism and absolutes and the retreat into relativism" as "one notable trend" and "growing international interdependence" as another, he declares that "the most dynamic movements in contemporary jurisprudential thought are directed outwards from the law, seeking as it were to locate law within the wider complex of social phenomena," and forecasts a "downgrading of law" through economic and social reductionism, ibid. at $24,31,40,41$ respectively. The sketch of the present situation in legal theory which I draw later in this essay speaks well of Stone's prescience in each of these regards.

6 G. Minda, "The Jurisprudential Movements of the 1980's" (1989) 50 Ohio State L.J. 599 at 643, 654. Minda's mainstream theorists are liberals, and his new critics are feminists, critical legal scholars, and legal economists. For a similar take on the same period, see A.G. Nasser, "Legal Theory in Late Modernity" (1991) 42 Mercer L. Rev. 909.

1. Intellectual and social histories focussing on American law and theory are increasingly available. I have found Paul Carrington's work particularly helpful in this regard. See e.g. P. Carrington, "The Revolutionary Idea of University Legal Education" (1990) 31 Wm. \& Mary L. Rev. 527; "Aftermath" in Essays for Patrick Atiyah (Oxford: Clarendon, 1991) at 113; "Butterfly Effects: The 
that (or any other) period. ${ }^{8}$ My much more modest purpose is, rather, to trace the origins of the present, legal theoretical situation and, then, briefly to appraise its moral and ethical significance for legal education, scholarship, and practice. I will not, therefore, provide an exhaustive account of any of the legal theories I canvass. Instead, my concern is the relations between the various intellectual trends as regards their contribution to the present configuration of theoretical attitudes towards law.

I will take as a vantage point in this endeavour a theoretical requirement announced by Ronald Dworkin in 1975. According to Dworkin, in order to perform responsibly their tasks, lawyers and especially judges:

must develop a theory of the constitution, in the shape of a complex set of principles and policies that justify that scheme of government.... [They] must develop that theory by referring alternately to

Possibilities of Law Teaching in a Democracy" (1992) 41 Duke L.J. 741 [hereinafter "Butterfly Effects"]; "Hail! Langdell!" (1995) 20 Law \& Soc. Inquiry 691 [hereinafter "Hail! Landgell!"]; "The Missionary Diocese of Chicago" (1995) 44 J. Leg. Ed. 467. See also G. Gilmore, The Ages of American Law (New Haven, Conn.: Yale University Press, 1977). For an excellent socio-legal history of American women, see J. Hoff-Wilson, Law, Gender, and Injustice: A Legal History of U.S. Women (New York: N.Y.U.P., 1991). Canadian histories of this sort are not available. Due to the "enigmatic and unparalleled longevity" of legal positivism in Canada, (G.B. Baker, "The Reconstitution of Upper Canadian Legal Thought in the Late-Victorian Empire" (1985) 3 Law \& Hist. Rev. 219 at 276), there is really, I suspect, no such history to report. I have canvassed the past and present state of theory in the Canadian legal academy elsewhere: see F.C. DeCoste, "Taking A Stand: Theory in the Canadian Legal Academy" (1991) 29 Alta. L. Rev. 941. In preparing the present essay, I consulted R. Boult, A Bibliography of Canadian Law, (Ottawa: Canadian Law Information Council, 1977) and discovered that on the most generous of counts, it lists forty-four legal theoretical works authored by Canadians during the period 1867-1975. Among which, see J.F. Davison, "The Study of Jurisprudence" (1929) 7 Can. Bar Rev. 438 at 438: "Properly defined Jurisprudence is the science of law in its widest possible aspect. It is therefore chiefly concerned with problems of justice and with formulae which lead to the right solution of difficult and obscure cases"; and ibid. at 444: "After years of realism and academic doubt, ... jurists are eagerly seeking some formulae which shall contain fundamental rules for the guidance of contemporary civilisation"; E. McWhinney, "English Legal Philosophy and Canadian Legal Philosophy" (1957) 4 McGill L.J. 213 at 215 considering "how far, if at all, [English legal positivism] is a viable philosophy of law for either the United Kingdom or for that matter for Canada, at mid-century"; ibid. at 216: concluding that there is "a burning need for any English Realist or Sociological movement in law ... to challenge the 'basic myth' that judges do not make law" and that Canada requires "some more affirmative, activist, instrumental philosophy of law than analytical positivism"; ibid. at 218: calling for the development of "an autonomous Canadian jurisprudence."

8 No such legal meta-theory is presently available: see M.S. Moore, "The Need for a Theory of Legal Theories: Assessing Pragamatic Instrumentalism" (1984) 69 Cornell L. Rev. 988. If one were to undertake constructing one, Kuhn's theory of paradigms would, I think, provide a necessary point of departure. See T.S. Kuhn, The Structure of Scientific Revolutions (Chicago: U. Chi. P., 1962). See also Minda, supra note 6 at 599; and A.R. Kamp, "Between-The-Wars Social Thought: Karl Llewellyn, Legal Realism, and The Uniform Commercial Code in Context" (1995) 59 Albany L. Rev. 325 at 396. 
political philosophy and institutional detail. [They] must generate possible theories justifying different aspects of the scheme and test the theories against the broader institution.'

This announcement, I propose, represents a turning point in Anglo-American legal theory, not because it is unique or first in time, ${ }^{10}$ and most certainly, not because I attribute to it wide-ranging causal force, ${ }^{11}$ but rather because it constitutes a final and full-blown concession that law and legal theory can no longer adequately be thought matters parochial to judges, lawyers, and legal scholars. Just the contrary Dworkin insists: because law - and thought about law - is part and parcel of a wider practice and conversation concerning human association, goals, and goods, to make sense of law and lawyering and judging, the legal community must reach out and claim its place at the table of that on-going discussion. Viewed in this light, Dworkin's announcement not only signals a maturation of legal discourse and, as we will soon discover, the completion of an intellectual trend begun much earlier, but in consequence, also distinguishes the past from the present in matters of legal theory.

Because it is all of these - a maturation and a completion and a demarcation - the announcement is an apt prominence from which to view the past, to understand the present, and to speculate about the future. From its vantage, the panorama is anything but prosaic. We will see law's conception change from autarky to integration and presently, perhaps to colonization and subordination. We will witness gradual but steady shifts from intellectual poverty to plenitude, from self-satisfied certainty to deep confusion, and from unquestioned security to ubiquitous vulnerability. Most importantly, we will discover that three, related moments in law's intellectual past are productive of the present we now inhabit.

9 R. Dworkin, "Hard Cases" (1975) 88 Harv. L. Rev. 1057 at 1085, reprinted in R. Dworkin, Taking Rights Seriously (Cambridge, MA: Harvard University Press, 1977) 81 at 107. See also ibid. at 149 where Dworkin praises John Rawls' A Theory of Justice (Cambridge, MA: Harvard University Press, 1972) as "an abstract and complex book about justice which no constitutional lawyer will be able to ignoren; Dworkin's A Matter of Principle (Cambridge, MA: Harvard University Press, 1985) at 370 where he declares that "a theory of rights ... is relative to the other elements of a political theory," that they "figure in complex packages of political theory"; and Dworkin's Law's Empire (Cambridge, MA: Harvard University Press, 1986) at 410: "law unites ... jurisprudence and adjudication".

For instance, long before Dworkin's announcement, American legal realists were declaring that making sense of law would require the legal community's reaching out to other disciplines. See e.g. F.S. Cohen, "Transcendental Nonsense and the Functional Approach" (1935) 35 Columbia L. Rev. 809 at 810: "the question of whether the action of the courts is justifiable calls for an answer in non-legal terms. To justify or criticize legal rules in purely legal terms is always to argue in a vicious circle." For a full statement of Cohen's view, see F.S. Cohen, "The Ethical Basis of Legal Criticism" (1931) 41 Yale L.J. 201; and F.S. Cohen, Ethical Systems and Legal Ideals: An Essay on the Foundations of Legal Criticism (Ithaca: Cornell University Press, 1933). Dworkin's requirement differs from the realist one - and from various contemporary functionalisms - in defining the intellectual and moral profit of reaching out to be indigenous to law.

"Though Dworkin has had much to do with intellectually liberalizing at least liberal legal theory and though he has served as a favourite foil for numerous "new critics," there are many factors which account for the variegation of legal theory more generally. For a view on this, see R.A. Posner, "The Decline of Law as an Autonomous Discipline: 1962-1987" (1987) 100 Harvard L. Rev. 761 at $766-77$. 
In the first part of this essay, I will briefly explore and relate one to the other, each of these moments. In the second part, I will characterize the intellectual and moral substance of the present which these moments have compelled. The third part - a conclusion really - is devoted to the future promised, or perhaps threatened, by this present and this past.

\section{THE PAST}

That the legal theoretical present is the product of three distinct moments in law's conceptual history is not controversial. Nor is this history's general character and chronology: a formalist moment commencing (in America at least ${ }^{12}$ ) around 1885, is followed by a realist moment throughout the 1920 s and 1930s, which moment in turn is followed by a period of re-adjustment and accommodation in the 1950s and the 1960 s. $^{13}$ Less certain are the intellectual origins of legal formalism ${ }^{14}$ and the theoretical and historical demarcations between it and the realism which followed. ${ }^{15}$ But these

Regarding the Canadian past, see supra note 7 and accompanying text.

For depictions of law's intellectual history roughly along these lines, see Minda, supra note 6; Carrington, supra note 7; N.E.H. Hull, "Vital Schools of Jurisprudence: Roscoe Pound, Wesley Newcomb Hohfeld, and the Promotion of an Academic Jurisprudential Agenda, 1910-1919" (1995) 45 J. Leg. Ed. 235; J.W. Singer, "Legal Realism Now" (1988) 76 Calif. L. Rev. 465; Golding, "Jurisprudence and Legal Philosophy in Twentieth-Century America - Major Themes and Developments" (1986) 36 J. Leg. Ed. 441; T.C. Grey, "Langdell's Orthodoxy" (1983) 45 U. Pitt. L. Rev. 1; G. Peller, "The Metaphysics of American Law" (1985) 73 Calif. L. Rev. 1151; E. Mensch, "The History of Mainstream Legal Thought," in D. Kairys, ed., The Politics of Law: A Progressive Critique (New York: Pantheon, 1982) at 18; and M. Speziale, "Langdell's Concept of Law as Science: The Beginning of Anti-Formalism in American Legal Theory" (1980) $5 \mathrm{Vt}$. L. Rev. 1. More generally, see M. Horwit,, The Transformation of American Law, 1780-1860 (Cambridge, MA: Harvard University Press, 1977); M. Horwit, The Transformation of American Law, 1870-1960: The Crisis of Legal Orthodoxy (Oxford: Oxford University Press, 1992); M.G. White, Social Thought in America: The Revolt Against Formalism (New York: Viking, 1949).

Paul Carrington, for instance, claims that for a variety of social and economic reasons, the legal formalist period in America not only supplanted, but in certain senses devolved from, a robust republican period: see "Hail! Langdell!" supra note 7 at 702-07; "Aftermath," ibid. at 133-134; and "Butterfly Effects," ibid. at 773-77. Incidentally, it is this lost tradition of lawyering which frequently is evoked as a model for redeeming a fallen, professional present: see e.g. A. Kronman, The Lost Lawyer: Failing Ideals of the Legal Profession (Cambridge, MA: Harvard University Press, 1993). Others associate legal formalism with English intellectual history and variously identify William Blackstone [Commentaries on the Laws of England, 3d ed. (Oxford: Clarendon, 1765) (1765)]; Jeremy Bentham [A Fragment on Government (London: Oxford University Press, 1931) (1776); and The Limits of Jurisprudence Defined (London: Athlone Press, 1970) (1782)]; John Austin [The Province of Jurisprudence Determined, 2d ed. (New York: Franklin, 1970) (1832)]; James Mill [Essays on Government, Jurisprudence, Liberty of the Press, and Law of Nations (New York: Kelley, 1967) (1825)]; and John Stuart Mill [Essays on Equality, Law, and Education: Collected Works of John Stuart Mill, Vol. XXI, ed. by J.M. Robson (Toronto: U. Toronto P., 1984) 1825-1871] as progenitors: see e.g. D. Kennedy, "The Structure of Blackstone's Commentaries" (1979) 28 Buffalo L. Rev. 205; Golding, ibid. at 442; and Carrington, "Aftermath," ibid. at 118, 142-144.

For instance, Oliver Wendell Holmes, Jr., John Chipman Grey, and even Christopher Columbus Langdell are oftentimes named as proto-realists: see "Hail! Langdell!" supra note 7 at 716-35; Golding, supra note 13 at 443-48; Speziale, ibid. at 30-35; and R.S. Summers, Instrumentalism and American Legal Theory (Ithaca: Comell University Press, 1982) at 176-90. And instead of antagonism, the theoretic relation between formalism and realism is sometimes claimed to be 
nuances and niceties will not delay us here. Instead, I will simply assume the division's rough readiness historically and conceptually, and proceed directly to what I take to be the nerve of the matter; namely, that what makes this history intelligible, the intellectual tissue which connects it both to its parts and to the present, is the question of the possibility of a language of normative argument indigenous to law. ${ }^{16}$ Dworkin's announcement, of course, represents the belief that law is, in this sense, seized of normative integrity. But our discovery of the conceptual content of law's formalist, realist, and accommodationist past will disclose the Dworkinian view as anything but prevailing. Later on still, when we come to the present, we will discover that the tone and temper of contemporary legal theory is, in most of its parts, defined as much as anything by a wholesale, utopian assault on views such as Dworkin's.

\title{
A. LAW AS AUTARKY: THE FORMALIST MOMENT
}

A year following his 1870 appointment as the first Dean of Harvard Law School, Christopher Columbus Langdell wrote the following in the Preface to his $A$ Selection of Cases on the Law of Contracts:

\begin{abstract}
Law, considered as a science, consists of certain principles or doctrines. To have such a mastery of these as to be able to apply them with constant facility and certainty to the ever-tangled skein of human affairs, is what constitutes a true lawyer.... [T] he number of fundamental legal doctrines is much less than is commonly supposed; the many different guises in which the same doctrine is constantly making its appearance, and the great extent to which legal treatises are repitition of each other, being the cause of much misapprehension. If these doctrines could be so classified and arranged that each should be found in its proper place, and nowhere else, they would cease to be formidable from their number. ${ }^{17}$
\end{abstract}

Langdell elsewhere declares that "all the available materials of that science are contained in printed books"18 and that the law library is the "proper workshop" for lawyers, since it is for them precisely what "the laboratories of the university are to the chemists and physicists, the museum of natural history to the zoologists, the botanical

complementary: see e.g. H. Stewart, "Contingency and Coherence: The Interdependence of Realism and Formalism in Legal Theory" (1995) 30 Valparaiso U.L. Rev. 1. For views which associate both formalism and realism with modernism, see Kamp, supra note 8 at 331; and Grey, supra note 13 at 2-6. See also Nasser, supra note 6 at 911-15.

See e.g. Singer, supra note 13 at 468, 504, 532. This question addresses what John Rawls calls the issue of "public reason," which is to say, whether there exists a vocabulary of institutional validation and practice which does not merely reduce to power or to personal perspective: see J. Rawls, Political Liberalism (New York: Columbia University Press, 1993) Lecture VI at 212-54. As we shall see, if such a language is impossible, we ineluctably become stuck in a perspectivism which equates argument with prejudice and declares law always the authoritarian and never the authoritative.

17 C. Langdell, $A$ Selection of Cases on the Law of Contracts, 1st. ed. (Boston: Little, Brown, 1871) at vi-vii. And yes, Langdell is responsible for the casebook method of legal education as well as for its three-year course of study: see "Butterfly Effects," supra note 7 at 778-80, and "Hail! Langdell!" ibid. at 707-14, and Speziale, supra note 13 at 12, 25. 
garden to the botanists." 19 I will take Langdell's view of law as a closed system akin to science ${ }^{20}$ and his view of legal practice as textual empiricism as the apotheosis of the formalist moment which it will be my concern here to lay bare critically. ${ }^{21}$

Space prevents any lengthy excursus into formalism, legal or otherwise. ${ }^{22}$ Instead, and preliminary to the more important matter of disclosing the consequences of the Langdellian view, I wish ever so briefly to discuss the conceptual positions legal formalism presumes. The belief that law is an independent, scientific discipline is buttressed by two peculiarly conceptual commitments - by a commitment first to formalism and by a commitment then to objectivism. Roughly put, a system of belief is formalist to the extent that it accords to the form of statements - be the preferred form, principles, rules, or laws - ultimate explanatory or justificatory force. ${ }^{23}$ Objectivism is formalism's epistemological corollary. In order to believe that one can be instructed and constrained by form, it is necessary also to believe that the form is available in a manner unmediated by one's peculiarities. Hence the objectivist commitment: in Langdell's case, the belief that the world of legal texts exists independent from our comprehension of it and that that world is accessible to us independently of any subjective viewpoint. That the formalist moment is formalist and objectivist in just these senses very much accounts for the whole of the law's subsequent conceptual history. For if the realist and accommodationist moments and

C. Langdell, "1886 Speech Delivered on the Occasion of the 250th Anniversary of Harvard University" (1887) 21 Am. L. Rev. 123 at 124. Also reprinted in (1887) 3 L.Q. Rev. 118. Cited in Speziale, supra note 13 at 14, 16. Followers of Langdell pushed the analogy to science even further. See e.g. Keener, "The Inductive Method in Legal Education" (1894) 28 Am. L. Rev. 709 at 713: after declaring "the case ... both a laboratory and a library," compares "the facts of the case ... to the specimen, and the opinion of the court, announcing the principles of law to be applied to the facts, ... to the memoir of the discoverer of a great scientific truth." For a discussion of Langdell's understanding of science, see Speziale, supra note 13 at 19-35. To claim that Langdell's views offer the quintessence of legal formalism is not to claim that they caused formalism historically: see "Butterfly Effects" and "Hail! Langdell!" supra note 7 at 799 and 707 respectively. For a view of the origins of formalism, see supra note 13 and accompanying text; M.J. Horwitz, "The Rise of Legal Formalism" (1975) 19 Am. J. Leg. Hist. 251. For a view of the sociological factors motivating Langdell - not the least of which, the desire to provide legal education stature within the university community - see "Butterfly Effects" and "Hail! Langdell!" supra note 7 at 763-76 and 711 respectively; Speziale, supra note 13 at 14, 25-26, 37. For varied forays into legal formalism, see F. Schauer, "Formalism" (1988) 97 Yale L.J. 509; P.S. Atiyah \& R.S. Summers, Form and Substance in Anglo-American Law: A Comparative Study of Legal Reasoning, Legal Theory, and Legal Institutions (Oxford: Clarendon, 1987); R.A. Posner, "Legal Formalism, Legal Realism, and the Interpretation of Statutes and the Constitution" (1986) 37 Case W. Res. L. Rev. 179; M.V. Tushnet, "Anti-Formalism in Recent Constitutional Theory" (1985) 83 Mich. L. Rev. 1502; R.M. Unger, "The Critical Legal Studies Movement"',(1983) 96 Harv. L. Rev. 561; D. Lyons, "Legal Formalism and Instrumentalism - A Pathological Study" (1981) 66 Cornell L. Rev. 949; Horwitz, ibid; and D. Kennedy, "Legal Formality" (1973) $2 \mathrm{~J}$. Leg. Stud. 351. More generally, see Horwitz, supra note 13. To sample the discourse in literary theory, see W.B. Michaels, "Against Formalism: The Autonomous Text in Legal and Literary Interpretation" (1979) 1 Poetics Today 23 and Against Theory: Literary Studies and the New Pragmatism, ed. by W.J.T. Mitchell (Chicago: U. Chi. P., 1985).

See Schauer, ibid. at 510: "At the heart of the word 'formalism,' in many of its numerous uses, lies the concept of decisionmaking according to rule. Formalism ... screen[s] off from a decisionmaker factors that a sensitive decisionmaker would otherwise take into account" [emphasis in original]. 
especially the present, are the aftermath of formalism, they are an aftermath born of a rejection of its fulsome formalism and its optimistic objectivism. ${ }^{24}$ But we must not get ahead of the story. This moment of legal history had a more accessible and transparent impact which very early along became the focus of what turned out to be a continuing critical concern. ${ }^{25}$ I am referring to the formalist view that the law is a distinct and entirely autonomous discipline and practice. It is to this understanding that we must now turn.

For the legal formalist, law is an autarkic enterprise requiring no truck or trade beyond its borders. Formalism and objectivism are the conceptual currency of this autistic legal economy; and like other, less sublime economies, this one too appears, in the final analysis, to have originated in self-interest. ${ }^{26}$ But since our interest is formalism's contribution to the course of law's conceptual history, we must direct our attention not finally to these intellectual and social origins, but instead to the form and consequences of the claim to autonomy to which they led.

Formalists claimed - and continue to claim ${ }^{27}$ - that law is autarkic in two senses. Consonant with their social objective of providing legal education and scholarship stature within the university, ${ }^{28}$ they claimed that law is a discipline entirely separate, distinct, and autonomous from all other academic disciplines. ${ }^{29}$ Consonant with their

For instance, over the past several years, the remnant of objectivism in law has spawned a virtual growth industry under the banner of law and interpretation: see e.g. "Symposium on Law Interpretation" (1985) 58 S. Calif. L. Rev. 1-725.

Dissent from the view that law is an autonomous and independent discipline can be dated as early as Holmes' review of Langdell's $A$ Selection of Cases on the Law of Contracts, supra note 17, in which Holmes for the first time famously declared "the life of the law" to be social "experience," and not "logic" and sympathetically characterized Langdell as "the greatest living legal theologian": see Holmes, "Book Review" (1880) 14 Am. L. Rev. 233 at 233-34. For more of Holmes on the life of the law, see Holmes, "The Path of the Law" (1897) 10 Harv. L. Rev. 457; and Holmes, The Common Law (1881) (Boston: Little, Brown, 1923). Incidentally, though the view that law is an autarkic enterprise originates in formalism and objectivism, early critics like Holmes rejected autarky while remaining fully committed, at least in a practical sense, to both of its conceptual buttresses: see Speziale, supra note 13 at 31-33; and "Hail! Langdell!" supra note 7 at 728-35. Though the attack on law's autonomy has continued unabated into the present, since the realists the focus has increasingly become the formalism and objectivism out of which the claim to autonomy is finally forged.

For commentary on Langdell's motivation in conceiving of law as science, see sources cited supra note 21.

For as we will shortly discover, notwithstanding the wholesale dismantling of formalism and objectivism, in many quarters, law continues to be taught and studied and practiced as if its intellectual history ended with Langdell: see Grey, supra note 13 at 39,51, 53 arguing that formalism "haunts us still" since "legal discourse largely retains its orthodox form" and remains enthralled with formalism's "coolly seductive fantasy." In my view, contemporary attempts to couple with formalism are unavoidably sterile since despite their best efforts, suitors of that temptress are plagued with an ironic disbelief which renders consummation quite impossible. See e.g. sources cited supra note 21 .

Though Langdell and his contemporaries cast this claim in terms of science, our review of the accommodationist moment will disclose the claim to be entirely severable from nineteenth century scientism. That the claim continues in redacted form is perhaps no better illustrated than in the legal academy's refusal to recognize study in any other discipline as necessary for legal study. This ubiquitous policy against requiring of candidates specific pre-legal studies makes sense, of course, 
formalism and objectivism, they also claimed that law is completely separate and autonomous from the particularities of social life. ${ }^{30}$ Together these claims yielded a view of law as "a closed system." ${ }^{31}$ According to this understanding, the integrity of law depends finally on its purity from, on the one hand, the intellectual and theoretical sources and traditions of other scholarly disciplines ${ }^{32}$ and, on the other, the values, commitments, and goals of human life and association. ${ }^{33}$ Rather than dallying over the nature of the relationship between these claims, ${ }^{34}$ we will turn our attention immediately to the much more important matter of the consequences of viewing law in this fashion.

I want to propose that the several consequences which necessarily attend the formalist understanding, together prohibit formalism from engaging, let alone articulating, any vocabulary on the basis of which to make sense of law normatively. This prohibition is an all-important feature of legal history, since it in short order drove jurists elsewhere in order to satisfy the manifest intellectual and social need to render law morally and ethically intelligible. As we shall see, this search for sense beyond law began a disenchantment of the law that has fully ripened only in the present. But to tell that tale, we have first to identify the consequences, and then to calculate the senses in which they are the commencement of that process.

In 1908, Roscoe Pound criticized formalist jurisprudence as "mechanical." ${ }^{35}$ By this, he meant to decry its blindness to and overall disconnection from the facts of social life, ${ }^{36}$ what latter day, ideologically-driven realists term its reification. ${ }^{37}$ In this, I believe Pound captured the moral nerve of the conceptual consequences which follow from a formalist understanding of law. That nerve is not that formalist law is apolitical

only if law is an entirely autonomous discipline which can, in consequence, be studied de novo. For summations of this view, see Grey, supra note 13 at 53; and Hull, ibid. at 244, 269.

See "Hail! Langdell!" supra note 7 at 710.

Ibid. at 714.

So much was this the case, that "for a brief time, Constitutional Law was not taught at Harvard Law School, presumably because of the manifest impossibility of discussing the subject without regard for its political consequences": ibid. at 710.

Though, as Speziale points out the first claim carried "no particular jurisprudential premises," and though through it, formalists understood law to share the formalism and objectivism characteristic of its fellow disciplines, it could be argued that the first claim depends on the second at least to the extent that it cleared the ground intellectually for the haphazard articulation of a vision for the study and practice of law: see supra note 13 at 35 . I deal with this vision immediately in terms of the consequences of the claim to autarky.

33 R. Pound, "Mechanical Jurisprudence" (1908) 8 Columbia L. Rev. 605. Pound's condemnation of the past as mechanical was the beginning of his attempt to develop a sociological jurisprudence with which to render law not only intelligible, but also, once again, socially significant. Regarding which, see Golding, supra note 13 at 448-52; and Hull, ibid. at 237-45. Pound's critique of formalism and his reaching beyond law to sociology are the intellectual precursors to the fullblown realism which was to follow. Unhappily, the space limitations placed on this paper prevent my canvassing at all fully the various intellectual paths from formalism to realism.

Golding, ibid. at $\mathbf{4 5 0}$.

I am referring, of course, to critical legal scholars for whom "reification" is a term of (much repeated) art. See e.g. Gabel, "Reification in Legal Reasoning" in S. Spitzer, ed., Research in Law and Sociology (Greenwich, Conn.: JAI P., 1980) 25. I briefly canvass critical legal studies when we come to discuss the legal present. 
since clearly autarky is itself "a political ideal" of sorts. ${ }^{38}$ Nor is it that legal reasoning is somehow mindlessly syllogistic. While formalists may indeed have been decidedly apolitical regarding the social consequences of legal and especially judicial decisionmaking and while those of them who early along associated formalism with science may well have taken legal reasoning to be a matter of simple-minded logic, ${ }^{39}$ neither of these proclivities captures at all adequately the feature which both distinguishes formalism and led subsequent thinkers to mine sustenance beyond the law.

That feature has, instead, to do with a view of legal morality and ethics which at a much more fundamental level, a formalist understanding of law implicates. I began this essay with a passage from Weber which declares lawyers the last possible persons who should engage in normative discourse. ${ }^{40}$ Weber's prohibition against normativity is not at all accidental. On the contrary, his commitment to formalism forbade him any choice in the matter, since the moral logic of formalism necessarily and always compels just such a morally and ethically stingy view of legal practice. Remember that for the formalist, law's integrity is its purity. It is just this limited legal morality, I want to propose, which requires an understanding of law which drives all formalists to embrace the Weberian injunction. For it is through this understanding that the formalist commitment to preserving law from contamination by the non-legal becomes finally a prescription with respect to the morality and ethics of legal practice.

To seek to exclude the social and intellectual world from law, of course requires the formalist to believe that law can operate in isolation from them. And it is the particulars of this belief which constitute the formalist view of law which, in turn, demeans law morally. The particular demanded is this: that law consist of rules or principles which are both discernable and followable. Only if this be so, may the law possibly be thought an autarkic enterprise independent from social and intellectual life. For if the law is not a system of rules or, even if it is, if those rules turn out to be neither discernable nor followable, then the formalist game is up and jurists would be compelled to look elsewhere for the sense of law. If, however, these beliefs are thought good, then jurists not only need not, they positively ought not, search elsewhere since to do so would be to contaminate the law.

Formalists, of course, thought - and continue to think - these beliefs true and good, and in consequence, legal practice became for them an iron cage constructed of prohibitions against moral curiosity, social innovation, and especially, ethical commitment. Under this view, the role of lawyers, simply and exclusively, is mechanically to follow the rules law lays down and their proper business is, therefore, one of professional expertise in so doing. ${ }^{41}$ But this leaves law a profession with nothing to profess. Sucked dry of politics and morality, and abstracted from normative

See Posner, supra note 11 at 762. For a more ideological view of the politics of formalism which associates formalism with the growth of merchant and entrepreneurial commerce, see Horwitz, supra note 21 .

39

40

41

Regarding which, see supra note 34; and "Hail! Langdell!" supra note 7 at 707-8.

Weber, supra note 1.

For an investigation of the formalist view of lawyers as technocratic experts, see "Butterfly Effects," supra note 7 at 777-86 and "Aftermath," ibid. at 132, 137. 
standards, legal ethics becomes reduced to technology and instead of standing for something, lawyers merely are those expert in the manipulation of law's autarkic currency. The moral and political and ethical aridity of all of this did not long beg for critique, a critique which with the realists, began an intellectual process culminating in the law's cultural and spiritual disenchantment.

\section{B. LAW AS FUNCTION: THE REALIST MOMENT}

According to Morris Cohen, by 1913, "[t]he philosophy of law" had "fallen into utter neglect." ${ }^{142}$ In 1931, Karl Llewellyn declared legal discourse a "canal of stagnant words, ${ }^{143}$ and described the legal theoretical consequences of this torpor as follows:

So other fields of thought have spilled their waters in: the stress on behavior in the social sciences; their drive toward integration; the physicists' re-examination of final-seeming premises; the challenge of war and revolution. These stir. They stir the law."

By the 1930s, that is, formalism's utter failure to nourish legal discourse and practice had resulted in a search for some moral, ethical, and political sense and sensibility beyond the law. Though its intentions and practices were diverse, this search has come to be considered the intellectual requiem of legal formalism, ${ }^{45}$ and its varied initiatives to be identified collectively as American Legal Realism. And so it will be considered here.

Now this cannot be the place to offer a detailed description of the many parts and practitioners of American realism. ${ }^{46}$ Nor do I wish to parse the realist attack on the formalist and objectivist buttresses of the autarkic understanding. ${ }^{47}$ Instead, assuming all of that and assuming too that, overall, the realists understood law in a functionalist

42 M.R. Cohen, "Jurisprudence as a Philosophical Discipline" (1913) 10 J. of Philosophy 225.

43 K.N. Llewellyn, "Some Realism About Realism - Responding to Dean Pound" (1931) 44 Harv. L. Rev. 1222 at 1222.

4 Ibid.

45 But as noted earlier, since formalism continues to structure much of legal discourse, this particular requiem's benedictus has never really ended: see supra note 27 .

t6 Regarding which, see Gilmore, supra note 7; Hull, supra note 13; Singer, ibid; Grey, ibid.; Mensch, ibid; and Summers, supra note 15. See also L. Kalman, Legal Realism at Yale: 19271960 (Chapel Hill: U. North Carolina P., 1986); W. Twining, "Talk About Realism" (1985) 60 N.Y.U.L. Rev. 329; Gordon, "Legal Thought and Legal Practice in the Age of American Enterprise, 1870-1920" in G. Geison, ed., Professions and Professional Ideologies in America (Chapel Hill: U. North Carolina P., 1983) 70; G.E. White, Patterns of American Legal Thought (Indianapolis: Bobbs-Merrill, 1978); and G. Gilmore, "Legal Realism: Its Cause and Cure" (1961) 70 Yale L.J. 1037.

47 There are reasons other than space for declining. The realist attack on formalism and objectivism was haphazard as judged by later intellectual standards. Its most enduring contribution is probably Jerome Frank's distinction between rule and fact scepticism: see J. Frank, Law and the Modern Mind (New York: Coward-McCann, 1949); and J. Paul, The Legal Realism of Jerome N. Frank: A Study of Fact-Scepticism and the Judicial Process (The Hague: Nijhoff, 1959). Recent antiformalism is more successful and sophisticated because it is informed by literary theory: see supra notes $22,24$. 
or instrumentalist fashion, ${ }^{48}$ I want to proceed directly to two matters which relate directly to our project of tracking the lineaments of law's conceptual past into the present. More particularly, I want to discuss, first, why realism came to an end, and then, its critical bequest to all future reflection on law.

Despite its "destruction of the formalist universe"49 and notwithstanding its "near total success in dominating post-Realist legal theory, ${ }^{1150}$ "as a coherent intellectual force, American Legal Realism simply ran itself into the sand." ${ }^{\prime 1}$ Numerous explanations have been proffered for realism's dying in the midst of its achievements. Schlegel, for instance, suggests that through a loss of intellectual nerve, the realists simply did themselves in. ${ }^{52}$ For his part, Gilmore thinks realism merely "a symptom" of an intellectual crisis in law - formalism's production of an "intolerably overburdened and unworkably complex" system of law - which was fated to pass with the resolution of the crisis. ${ }^{53} \mathrm{Kamp}$, on the other hand, claims that "World War II forced a moral choice [which] compelled an end to the Legal Realists' scepticism and their scientific detachment from moral issues. ${ }^{1.54}$ But I'll not labour the illustrations. For whatever their diagnostic value, for our purposes, the truth lies elsewhere. Singer claims that what is critically true of the realists is that they "were unable to produce an acceptable alternative to formalism that would enable judges and lawyers to engage in normative argument."15s Sociological speculations aside, so far as law's intellectual history is concerned, Singer's point is telling. For in terms of that history, realism died precisely because it was unable to respond to the demand for the development of a moral vocabulary indigenous to law. That realism itself in large measure first articulated this requirement makes its failure conceptually interesting. That that demand continues to govern legal theory makes disclosing the cause of the realist failure critical. And it is to this that I will now turn.

Herbert Hart draws a distinction between internal and external points of view with respect to law..$^{56}$ The internal is, above all, the point of view of members of the legal community, and is characterized by what Hart terms "a critical reflective attitude" which signals a normative engagement with law as a principled system. ${ }^{57}$ The external point of view, on the other hand, is the perspective of the observer. In contrast to the

See Ethical Systems and Legal Ideals, supra note 10 at 42, where Felix Cohen put this instrumentalism as well as any realist: "[T] he instrumental value of law is simply its value in promoting the good life of those whom it affects." See also Summers, supra note 15; and Kalman, supra note 46.

J.H. Schlegel, "American Legal Realism and Empirical Social Science: The Singular Case of Underhill Moore" (1980) 29 Buffalo L. Rev. 195 at 197.

Ibid. at 198. I deal with the nature of this success shortly.

Ibid. at 195.

Ibid. at 196: "their jurisprudential activities gave out when, faced with the implications of their own constructions, the protagonists lost their nerve."

Gilmore, supra note 46 at $1047-48$.

Supra note 8 at 394.

Singer, supra note 13 at $467-68$. See also ibid. at 504, 532, 541, 543. See also supra note 16.

H.L.A. Hart, The Concept of Law, Ist ed. (Oxford: Clarendon, 1961) at 54-56, 96, 99, 134, 242 [hereinafter The Concept of Law].

Ibid. at 56. 
acceptance and engagement characteristic of the internal, ${ }^{58}$ the attitude of the observer is defined by clinical distance; and instead of encountering principled integrity, the observer discovers in law, mere behaviour, a datum to be recorded and analyzed. ${ }^{59}$

The realists took the observer's attitude to law. That is, as encountered by them, law was not a system seized of normative integrity, but a body of behaviours to be described, analyzed, and above all else, manipulated for a variety of progressive social ends. ${ }^{60}$ The realists' failure to articulate a normative vocabulary for law owes everything to their proceeding from this, the outsider's perspective. But that discovery will not by itself provide the instruction we require with respect to the subsequent course of legal theory. To coax that lesson, we must attempt to identify both the reasons for, and the consequences of, their taking the view from without.

The epistemological attitude of the realists was, of course, influenced by their instrumentalism and indeed by their critique of formalism and objectivism. For, clearly, if one thinks both that law is an instrument endlessly manipulable to various external social ends and that what matters regarding those ends is not the law itself, but external policy attitudes which legal actors, and judges in particular, carry into the law, then one will be entirely predisposed to the observer's behaviourist attitude. ${ }^{61}$ But it appears to me that the lesson we seek requires us to dig still deeper. Singer provides us a clue here as well. He claims that "as a larger enterprise," realism was a historicist revolt against an ahistorical formalism:

The legal realists wanted to replace formalism with a pragmatic attitude toward law generally. This attitude treats law as made, not found. Law therefore is, and must be, based on human experience, policy, and ethics, rather than formal logic. Legal principles are not inherent in some universal, timeless logical system; they are social constructs, designed by people in specific historical and social contexts for specific purposes to achieve specific ends. Law and legal reasoning are a part of the way we create our form of social life. ${ }^{62}$

The liberating contingency which historicism always yields is not, however, without burden. For once the world is put up for grabs, it becomes the obligation of historical actors to find resources to make moral and political sense of a fully, historicized human situation. ${ }^{63}$ And so it was for the realists. I want to propose that at the most fundamental level, the realists' failure to produce a normative vocabulary for law was itself a product of their failure to act on the obligation which their declaration of legal contingency visited on them. Instead, the realists took refuge in a shoddy scepticism from which they could muster nothing more than a crass political decisionism. Let me briefly explain.

Jbid. at 99.

Ibid. at 134.

See Singer, supra note 13 at 475-99, and Golding, ibid. at 452-59.

Singer touches on both these matters: see Singer, ibid. at 470-75.

Ibid. at 474.

For a view of law's central role in this undertaking, see Nasser, supra note 6 at 915. 
The burden of formulating alternatives to a necessity lost to contingency - which in the realists' case, became the burden of devising alternatives to a destroyed formalism - may, of course, be discharged or avoided or shirked. While it would be unfair to say that the realists shirked this responsibility, it is probably true to say that they studiously avoided it. Perhaps the silly and unsophisticated scepticism they deployed in their attack on formalism prevented their developing the moral imagination required to formulate an "otherwise." But whatever finally is the case in that regard, one thing is certain: instead of shouldering the modernist burden, the realists either succumbed to the easy seduction of decisionism or sought false solace in scientism. ${ }^{64}$

Decisionism is "the belief that moral propositions are founded only on the choices or commitments of the individual." 65 Which is to say, since judgment is not accessible to reason, it is irreducibly and exclusively a matter of a decision which however it is made, is always arbitrary at least to the extent that it is grounded on nothing more substantial than the happenchance of the perspective of the decision-maker. For our purposes, decisionism is a decision to abdicate the search for a defensible normative language, in a very critical sense, to resign to perspectivism the possibility of a public reason beyond prejudice and power. ${ }^{66}$ I cannot here further explore - let alone adequately defend - this proposal through an interpretation of realist texts. ${ }^{67}$ Instead, I wish to offer a partial demonstration through a brief exploration of the realists' decidedly decisionistic view of judging ${ }^{68}$ After discussing this, the consequence to which I referred earlier, we will proceed to the matter for which our story is essential, the realists' theoretic bequests to the future.

Singer claims that the realists "sought to base legal reasoning on pragmatism." Pragmatism is the epistemological belief that knowledge is derived from experience and

Since decisionism has much more to do with the story we're pursuing, I will not here deal with realism's scientistic practitioners. For an excellent essay which does so, see Schlegel, supra note 49. Incidentally, my excluding scientism is not meant to diminish its continuing importance. Although I will shortly offer a different view, some interpretations of realism's theoretical bequest to the future highlight, among other matters, its scientism which they trace into contemporary attempts, such as law and economics, to tame an unruly contingency. For such a view, see Minda, supra note 6 at $635 \mathrm{ff}$.

D. Cornell, "Toward A Modern/Postmodern Reconstruction of Ethics" (1985) 133 U. Penn. L. Rev. 291 at 300 . See also Haarscher, "Perelman and Habermas" (1986) 5 Law and Philosophy 350 at 338, defining decisionism as "the acceptance of the impotence of reason regarding aims and values"; and F.R. Dallmayr, "Ontology of Freedom: Heidegger and Political Philosophy" (1984) 12 Political Theory 204, characterizing decisionism as arbitrary voluntarism. See supra note 16.

67 The realists have left us an abundance of texts for such an undertaking. Among them, I think the works of Felix Cohen and Karl Llewellyn are the most intriguing in this and most other regards. Regarding Cohen, see supra note 10. Regarding Llewellyn, see supra note 2; The Bramble Bush (New York: Oceana Publications, 1958); The Common Law Tradition: Deciding Appeals (Boston: Little, Brown, 1960); "On the Good, the True, the Beautiful, in Law" 9 U. Chi. L. Rev. 224; "On Reading and Using the Newer Jurisprudence" (1940) 40 Columbia L. Rev. 581; "A Realistic Jurisprudence - The Next Step" (1930) 30 Columbia L. Rev. 431; "The Rule of Law in Our Case-Law of Contract" (1938) 47 Yale L. J. 1243. 
that truth is instrumental, a mere means whose sole value is the attainment of our goals. To the extent that the realists thought legal reasoning pragmatic in just these senses, they unavoidably committed themselves to decisionism in law. This decisionism, along with its characteristic perspectivism, appears unrepentant in the "four broad propositions" which comprise the realist view of legal reasoning, ${ }^{70}$ what Karl Llewellyn called "Grand Style judging."

They believed, first of all, that "it is impossible to induce a unique set of legal rules from existing precedents." ${ }^{72}$ This rejection of constrain by precedent cleared the way for a second belief which begins the realist slide towards decisionism. As put by Holmes, because "general propositions do not decide concrete cases," decision becomes instead to "depend on a judgement or intuition more subtle than any articulate major premise." ${ }^{73}$ Accordingly, though cast in its language and logic, judicial decisions are not a consequence of law, but an expression of the values and morality of the judge. In a third move, the realists attempted to cabin judicial perspectivism by directing judges to base their decisions "on a thorough understanding of contemporary social reality." ${ }^{74}$ But once let loose, decisionism is a horse not so easily tamed. Neither finesounding platitudes about "situation-sense" 75 nor near-utilitarian prescriptions about "weighing considerations of social advantage" ${ }^{1176}$ can serve as substitute for the constraint that truth alone provides. After having so enthusiastically and blithely destroyed legal truth, the realist belief that judges could yet make "policy and precedential judgments without injecting personal political commitments into their decisionmaking" was utter delusion. ${ }^{77}$ For the reality to which the realists were otherwise so committed tells a very different tale. Once perspective becomes decision's measure, the decisionism which inevitably follows cannot then be restored to respectability through any such scientistic or sociological alchemy. Rather, like love, once lost, truth is forever and completely gone, there being no half measures in either.

Its decisionism, its inability to address the issue which it made central, its failure to develop a normative language for law, its hiding in scientism and scepticism, its offering platitudes rather than solutions, these together sealed realism's fate as an ongoing intellectual enterprise. Yet in another much more important sense, realism remains with us, and not in any mere spectral fashion. For however frail its positive contributions, realism changed for good all subsequent discourse about law. In my view - and putting aside the realist origins of much contemporary theory ${ }^{78}-$ it did

Ibid. at 499-503.

See The Common Law Tradition, supra note 67 at 62-72. Quoted in Singer, ibid. at 499. Singer, ibid.

Lochner v. New York, 198 U.S. 45 (1905). Quoted in Singer, ibid. at 500. It was precisely this sense of the matter that led Jerome Frank to formulate a psychoanalytic theory of the origins of judicial intuition: see Law and the Modern Mind, supra note 47.

Singer, ibid. at 501.

See Llewellyn, The Common Law Tradition, supra note 67 at 60 . Quoted in Singer, ibid. at 501. O.W. Holmes, "The Path of the Law" (1897) 10 Harv. L. Rev. 457 at 465-68. Quoted in Singer, ibid. at 501-2.

Singer, ibid. at 502 .

I briefly deal with this matter when we come to discuss the present situation. 
so in three critically important ways which together constitute its continuing bequest to those of us who reflect theoretically about law. ${ }^{79}$

First, and despite subsequent efforts at reconstruction to which we will turn shortly, realism destroyed, once and for all, the formalist and objectivist borders which insulated law from the untidy currents of a wider intellectual and cultural life. As put by Llewellyn, realism dismantled the dam built during law's autarkic moment and in turn spilled the nourishing, intellectual water of other disciplines. ${ }^{80}$ This spillage has since become a torrent. And if law was then stirred from torpor, it is now provoked by commerce from every conceivable quarter and of every possible cargo. So we may safely say that whatever else realism may have accomplished, it opened up the law. Law would never again be the simple villager among cosmopolitans. Because of realism, the comforting parish of impoverished autonomy has long since been deserted, and law has both claimed and been accorded status as an intellectual partner in the business of the humanities. That this has also produced a corrosive disenchantment of law is a matter with which we will deal presently. For now, it suffices to understand that the magna of the Dworkinian prominence which we will continue to climb, is realist to its core.

Not only, however, did realism open the law, as we have just seen, it did so in a fashion which set a specific jurisprudential agenda. In both forbidding any reprieve in formalism and failing to articulate an alternative normative paradigm, the realists condemned future theorists to labour at just that formidable task. Whether the task is worthy, whether on any measure, dedication to constructing a normative language for law is either possible or proper, whether absent such a language, law is reduced to institutionally-masked power and prejudice, whether the very notion of public reason makes moral and political sense, are issues which both confront and divide theorists. We will canvass those divisions when we come to the conceptual present. Once again, for now, it is enough to recognize that the present was landscaped by the realists.

But their handiwork did not end there. In addition to opening law and however haphazardly establishing what subsequently became its core theoretical issue, the realists also constructed two intellectual positions with which future theorists would be confronted in coming to jurisprudence. These sites of reflection correspond in broadbrush to the two strands of legal realist scholarship. Peller identifies a "deconstructive, debunking strand" 81 which he associates especially with the work of Felix Cohen ${ }^{82}$ and a second strand associated with Karl Llewellyn ${ }^{83}$ which in Peller's view is characterized by "the call for an explicit legal science through which law would

This is not meant to diminish realism's more wide-ranging, if poorly recognized, influence on other parts of the legal community. For despite the fact that legal discourse, particularly as used by bench and bar, retains a pronounced formalist accent (see supra note 27), the lessons of realism are very much a part of every lawyer's furniture of mind, and its language - think of balancing and policy - has become a lingua franca of the whole legal community.

so See supra note 44.

s1 Supra note 13 at 1223.

32 See supra note 10.

83 See supra note 67. 
be guided by objective facts of social life." 84 Minda too discovers two "different strands of realist thought"85 which he terms "realism as critique" and "realism as science. ${ }^{186}$ However the matter is put, ${ }^{87}$ this much, I think, is beyond dispute: that through their scholarship, the realists prepared for future scholars two ways in which to approach law from an external perspective. The first of these takes the observer's obligation to be critique and her practice to expose and then to defame and demean law's pretensions. The second is more benign, and instead of criticism, instructs the scholar-observer to provide law much-needed, constructive assistance from extra-legal sources.

Neither of these positions, of course, takes law at all seriously as an independently valuable, intellectual or moral undertaking and discipline. Yet they very much continue to define a broad and fully occupied spectrum of theoretical views about law. Indeed, along with what we may term the Dworkinian position, the outsider positions first articulated by the realists comprise the whole of the places from which law now may be approached ethically and morally. ${ }^{88}$

\section{LAW AS AUTARKY REDACTED: THE ACCOMMODATIONIST MOMENT}

Though opposition to realism began almost immediately, ${ }^{89}$ for present purposes, the reaction which must occupy us occurred in the 1950s and 1960s. I say reaction rather than opposition because what characterizes these later initiatives is less antipathy towards realism than an intention to accommodate law's independence to what was by then taken to be the common sense of the realist attack on formalism. This project of reconstruction was, of course, undertaken by numerous scholars using a variety of theoretical languages. ${ }^{90}$ We, however, will concern ourselves primarily with Herbert

Peller, supra note 13 at 1226.

Supra note 6 at 634.

Ibid. at 636. Like Peller, Minda associates the former, "deconstructive approach" with Felix Cohen and the latter, "social sciences" approach first with Karl Llewellyn and then with Jerome Frank: ibid. at 634-35.

Schlegel, for instance, offers an account different in tone from Peller's and Minda's: see supra note 49 at 197-201.

This is not to claim that the outsider jurisprudence of the realists appeared unassisted. For a view which associates realism - and critical legal studies, radical feminism, and critical race theory with the Marxist critique of law, see R.A. Belliotti, "The Legacy of Marxist Jurisprudence" in D.S. Caudill \& S.J. Gold, eds., Radical Philosophy of Law (Atlantic Heights, N.J.: Humanities P. Int'l, 1995) 3 at 23-31.

For a particularly insightful response - as well as for sources of other contemporary criticism see Mechem, "The Jurisprudence of Despair" (1936) 21 lowa L. Rev. 669.

In addition to the work of Herbert Hart to which we will come momentarily, of particular importance are the process theory formulated by Henry Hart and Albert Sacks and the modified and modest natural law theory of Lon Fuller. See H. Hart \& A. Sacks, The Legal Process: Basic Problems in the Making and Application of Law (Westbury, N.Y.: Foundation P., 1994); and L.L. Fuller, The Morality of Law, supra note 4. As in a different way did Herbert Hart, Hart and Sacks and Fuller sought to reassert the independence of law without recourse to formalism. We will soon learn that these efforts were futile precisely because they did not take realism at all seriously enough and because, in consequence, they failed to recognize that law's integrity could only be 
Hart's sophisticated attempt at postrealist jurisprudence if only because his failure so eloquently reveals both the impossibility of returning to even a modified formalism and the unalterable and unavoidable need, if law indeed is to be redeemed following realism, to construct a full-blown normative vocabulary indigenous to law. ${ }^{91}$

Hart sought to reassert law's autonomy by first confessing and then avoiding the realist critique. Key to this most lawyerly of manoeuvres are his redefinition of formalism and his reformulation of realism. For according to Hart, formalism is the intellectual vice of refusing to acknowledge what he took to be the realist lesson, that judicial choice is indeed sometimes necessary and inevitable to the application of legal rules. ${ }^{92}$ This, of course, redefines by trivializing the formalist claim and reformulates by marginalizing the realist critique. Yet it is just these moves which ground Hart's postrealist jurisprudence and his project of preserving for law a terrain of decision and judgment beyond choice. To calculate the size of that terrain, Hart deployed his now famous core-penumbra distinction. Derived from the ordinary language philosophy which at the time ruled the British academy, ${ }^{93}$ this metaphor expresses the view that most of the time, the meaning of language is available in a clear, unequivocal, and unmediated fashion. It is only sometimes, at the margins of meaning, in Hart's penumbra, that language fails to rule and meaning is "open" and requires interpretation and therefore choice. ${ }^{94}$ In Hart's view, the great swath of legal cases fall to the core. They are what he terms "plain cases" where "our linguistic resources" drive meaning with "syllogistic" clarity.

As did the original formalists before him, Hart in these ways pins law's integrity on the constraining power and authority of language. And though he refuses his version the name formalism, sustains it by different intellectual means, and accommodates it to realism by admitting that it is less than seamless, formalism it remains all the same. For not only does Hart's theory ground constraint in legal form, it does so with the aim of once again insulating law from the untidiness of intellectual and social life.

redeemed through provision of a full-blown normative vocabulary.

Though I cannot here trace the connections - and though Hart appears to take pains to deny them - Hart's project appears to owe much to the work of Hans Kelsen: see H. Kelsen, General Theory of Law and the State, trans. A. Wedberg (Cambridge, MA: Harvard University Press, 1945) and "The Pure Theory of Law: Its Method and Fundamental Concepts," trans. C. Wilson (1934) 50 L.Q. Rev. 474 and (1935) 51 L.Q. Rev. 517. For present purposes - see infra note 96 - it is sufficient to note that Kelsen's attempt at postrealist jurisprudence, though grounded in a different intellectual tradition than Hart's, came to much the same end both in terms of accomplishment and consequences. For a view of Hart's debt to Kelsen, see supra note 5 at 20. philosophy, are resolvable by analysing the meanings, forms, and functions of ordinary language. Names associated with ordinary language philosophy include John L. Austin, Ludwig Wittgenstein, G.E. Moore, Gilbert Ryle, and John Wisdom. In The Concept of Law, ibid., Hart mentions both Austin and Wittgenstein. 
There is no present profit in testing the ordinary language foundations of Hart's formulaic jurisprudence, in asking after the intelligibility of the core-penumbra distinction, or in analysing the meaning of clarity in legal language. What must concern us rather are the implications of his redacted and more modest formalism. More particularly, we must determine whether his jurisprudence is really postrealist at all and whether it provided any basis for meeting the realist challenge of formulating a normative language for law.

I want to suggest that to the extent that it embraces decisionism, ${ }^{96}$ Hart's philosophy continues, rather than concludes, the realist disenchantment of law and that that continuance in combination with his all-too-easy formalism forbade him taking seriously, let alone engaging, the realist challenge. Though he fudges the matter, Hart is committed to the view that in hard cases, those which fall in that penumbra beyond law's linguistic clarity and authority, brute decision alone rules. The fudge is his prescribing that even such legally groundless decisions "display characteristic judicial virtues" including "impartiality and neutrality ... and a concern to deploy some acceptable general principle as a reasoned basis for decision." ${ }^{197}$ But this attempt at closure fails to avoid decisionism - or, in consequence, to redeem law from simple power - because in constructing the penumbra, Hart put beyond reach any such solution. If in the penumbra, "judicial decision ... involves a choice between moral values, and not merely the application of some single outstanding moral principle," and if in the end, the legality of such decisions turns not on legal principle, but on their subsequent acceptance by other judges, ${ }^{99}$ then closure is unthinkable and unworkable and the "creative choice" which remains is wrapped in a decisionism every bit as robust as that endorsed by the most enthusiastic of realists, platitudes about voluntarist virtue notwithstanding. ${ }^{100}$

Hart perhaps thought this concession to law's vulnerability to power no matter since in his view, if law is indeed so prey, power may only bounce at the margins. In the great wealth of its operation, he thought, legal language insulates law from power by compelling results with a mechanical precision which renders choice and therefore power, predators with nothing to hunt. Hart's neoformalism is, of course, the magic which works this optimism. As I have indicated, we will not here put to the test its ever-so-frail foundations. What we will instead do is concede the point and inquire after what in the final analysis, his formalism, freely given, purchases. The answer to that

See supra note 65 and accompanying text. Hart was not the only postrealist theoretician to fall prey to decisionism. Kelsen's "grundnorm" likewise provides the whole of law a decisionistic foundation. See Kelsen, supra note 91. Nor does Hart's decisionism end with his view of law in hard cases which we'll explore in a moment. Indeed in as much as his theoretic edifice is founded on what he terms "the rule of recognition," his entire legal philosophy may fairly be said to be decisionistic, since the rule of recognition on which all else, including his formalism, depends, is in the final analysis a matter of a morally unconditioned consensus among legal officials. See Hart, ibid. at 111.

Hart, ibid. at 200.

Ibid.

Ibid. at 149.

Ibid. 
question is, I think, not much. For if Hart's formalism preserves law from power, it does so at the cost of rendering law a morally and spiritually empty undertaking characterized above all else by the mechanical operation of legal rules.

That this is just the result is no better demonstrated than in Hart's famous and unaccountably influential debate with Lon Fuller about the relationship between law and morality. ${ }^{101}$ According to Fuller, conformity with certain moral norms ${ }^{102}$ is a necessary condition for the existence of law. For his part, Hart maintained that since what makes a system of rules legal is not its moral features, ${ }^{103}$ the concept of law is entirely separate and distinct from the concept of morality. The Hart-Fuller debate, then, is about nothing more uplifting than the proper definition of the term "law." That Hart's intention was to preserve moral criticism from law ${ }^{104}$ or that Fuller's project was to associate a morally thin proceduralism with a more robust and progressive legal instrumentalism, ${ }^{105}$ that both thought their debate a moral one subject to moral criteria, in the end does not really matter. Nor does it at all matter who was right. For the philosophy of neither is capable of nourishing the law or meeting the realist challenge. As witness their sterile and misconceived contest, their philosophies instead leave law ethically and morally barren. In Hart's case, law becomes a curious mix of untrammelled decisionism and mindless syllogism. For Fuller, law is a purposive instrumentalism conditioned by the barest procedural morality. Though both attempt to take law seriously, these views prohibit their doing so since each forbids law any significant, indigenous moral or ethical substance. Success at provisioning law with just such a cargo had to await the present. And it is to the present which our story now takes us.

See H.L.A. Hart, "Positivism and the Separation of Law and Morals" (1958) 71 Harv. L. Rev. 593; and L.N. Fuller, "Positivism and Fidelity to Law - A Reply to Professor Hart" (1958) 71 Harv. L. Rev. 630.

Fuller's norms are procedural and therefore moral only in very thinnest of senses. See The Morality of Law, supra note 4.

103 In The Concept of Law, supra note 56, Hart theorizes what he terms the minimal moral content of law. But this concession to morality provides no opportunity for constructing a normative vocabulary for law since it was not itself made on moral grounds. Hart's intention was simply to articulate the conditions minimally necessary for the efficacy of legal systems. See ibid. at 188-94. In so doing, in theorizing a "sense that there is something outside the official system," some source of "moral scrutiny" to which the "demands [of law] must in the end be submitted," Hart was seeking to allow for resistance to wicked legal systems. He puts his case as follows:

Wicked men will enact wicked rules which others will enforce. What surely is most needed in order to make men clear sighted in confronting the official abuse of power, is that they should preserve the sense that the certification of something as legally valid is not conclusive of the question of obedience, and that, however great the aura of majesty or authority which the official system may have, its demands must in the end be submitted to a moral scrutiny. This concern led him as well to define his internal point of view as normative rather moral. See ibid. at 56-57, 96-99, 134, 206.

105 See The Morality of Law, supra note 4 at c. IV; and L.L. Fuller, "The Lawyer as an Architect of Social Structures" in K.I. Winston, ed., The Principles of Social Order: Selected Essays of Lon L. Fuller (Durham, N.C.: Duke U. P., 1981) at 264. 


\section{THE PRESENT}

Since the accommodationists only accommodated law to realism by "in effect and purpose," "downgrading" law, ${ }^{106}$ whatever success they may have had in preserving law's autonomy was meagre and Pyrrhic and failed at all to stem the floodtide of discourse described by Llewellyn so many years before. ${ }^{107}$ In consequence, the legal theoretical present - which for our purposes, we may date from Dworkin's initial critique of $\mathrm{Hart}^{108}$ - is not so much an aftermath as a continuation, indeed an accentuation, of the deluge. Jurisprudence is now polyglot. ${ }^{109}$ Liberal legal theory continues apace. As do various versions of traditional left thinking, marxist and socialist. Neoleftisms declare themselves adjectivally as "critical," as critical legal studies or critical race theory. The less politically convinced, on the other hand, are apt to declare their speech as "postmodern" in some hazy sense or another. There are several "law and's": law and literature, law and society, law and economics. Feminism takes numerous legal expressions, from the radical to the liberal to the cultural to the psychoanalytic. Gay and lesbian and most recently "queer" theory have found jurisprudential voice. And so on and on. ${ }^{110} \mathrm{~A}$ babel? For reasons which will become apparent, I think not. But as Minda is concerned to point out," no polyphony either. Perhaps something less comforting and more sinister than either. Or so at least, I will shortly argue. But first we must somehow put to score all of this speech about law.

A genealogical score is available. ${ }^{112}$ For instance, present trends in legal theory may, as we have discovered, ${ }^{113}$ be traced to realism, ${ }^{114}$ and in the case of a whole array of antiliberalisms, further back still to Marx ${ }^{115}$ and even beyond. ${ }^{116}$ But we will here follow a different notation. Instead of organizing the present with reference to intellectual history, the order we seek to disclose is one indigenous to these vocabularies themselves. And for this purpose, I want to redeploy Hart's distinction between the internal and external points of view. For in my view what finally orders the legal theoretical present, what prevents it from being the babel it otherwise most certainly would be, is not the intellectual idioms deployed by theorists nor the cultural

106 Stone, supra note 5 at 41

107 See supra note 44 and accompanying text.

108 See Taking Rights Seriously, supra note 9, c. 2 and 3.

109 Which is not to say that legal theoreticians are polymaths.

110 Any list can only be as complete and accurate as the tables of contents in the most recent issues of certain, trend-setting, elite law journals. These journals - need I say? - are all American, and despite the proliferation of alternative journals, everyone involved in the legal theoretical game can readily identify the leaders in law's intellectual style. And yes, Harvard and Yale journals would come to the mind of all.

III See supra note 6 at 650-61.

112 And not just one. In addition to the intellectual histories mentioned here, genealogies which associate present trends with, among other matters, the sociology of the post-1960s professorate have also been offered. For a view along these lines, see Posner, supra note 11 at 766-77.

113 See supra notes 85-87 and accompanying text.

114 See e.g. Minda, supra note 6; Peller, supra note 13; and Singer, ibid.

$115 \quad$ See Belliotii, supra note 88.

116 For an excellent intellectual history of this sort, see S. Holmes, The Anatomy of Antiliberalism (Cambridge, MA: Harvard University Press, 1993). 
terrain which they might be considered - or consider themselves - to occupy; what orders the present, rather, what renders it intelligible intellectually, morally, and ethically, is the attitude with which contemporary theorists approach law, whether they come to law with the perspective of the participant or of the observer.

Recall ${ }^{117}$ that Hart takes the internal point of view, the point of view of critical and normative engagement with law, above all else to be the perspective of members of the legal community. The external perspective, on the other hand, a point of view devoid of normative engagement and characterized by a clinical distance and the vivisectionist's interest, is the outsider's point of view. ${ }^{118}$ I want now to suggest that it is just these perspectives, the moralities of engagement which they define and represent, which both order and explain and render so troublesome and threatening the present.

Liminal contradictions aside - basic commitments, for instance, forbid the marxist theorist the internal point of view ${ }^{119}$ - what attitude a theorist takes to law is not a matter of the theoretical idiom he or she deploys. For instance, marxists and postmarxists among them excluded, feminists may as easily adopt an internal attitude as an external one. ${ }^{120}$ Likewise race theorists, postmodernists, and queer theorists. This is so because the internal point of view does not require blind submission to law or forbid criticism. Indeed, as Hart realized, just the opposite is the case since for the insider, law is a fertile ground for protest, resistance, and especially criticism. ${ }^{121}$ Whether a theorist takes an internal or external attitude depends rather on a much more fundamental, moral and ethical appraisal of law. ${ }^{122}$

If one thinks that "legal ideas [and ideals] embody and sustain a defensible scheme of human association,"123 that "they display," however imperfectly, "an intelligible

117 See supra notes $56,57,58,59$ and accompanying text.

118 Hart is careful not to limit the internal point of view to legal insiders. His intention in making the internal perspective characteristic of the legal community was not exclusion, but identification of a condition he thought necessary for the existence and survival of law: Hart, supra note 56. I shall return to the substance of Hart's sentiment elsewhere in this eassy.

119 Yet, as witness Fuller and Llewellynian realists, one may be a liberal, though not a jurisprudential liberal, and take an outsider's attitude to law. This is possible only because liberalism distinguishes between personal and political commitments. That marxists are forbidden the internal point of view is a matter we cannot pursue here though it has everything to do with the very same reasons marxism cannot articulate a theory of justice. Concerning which, see Dworkin, Law's Empire, supra note 9 at $74-75,408,425$. To sample the liberal turn in feminism, see K.T. Bartlett \& R. Kennedy, eds., Feminist Legal Theory: Readings in Law and Gender (Boulder, CO: Westview Press, 1991).

121 Yet for reasons already canvassed, Hart was careful to distinguish the internal point of view from - and not to require of it - moral engagement. See supra note 104. I will later argue that law and legal theory require just such an involvement.

122 For an early exploration of the connection between legal theory and morality on which my assertion in part depends, see D. Lyons, "Moral Aspects of Legal Theory" in P.A. Finch et al., eds., Midwest Studies in Philosophy VII 1982: Social and Political Philosophy (Minneapolis: Minnesota University Press, 1982) at 223. 
moral order,"124 and if one believes that law permits persons to be persons of a somehow desirable sort - if, that is, in broadbrush, one appraises law positively morally and ethically ${ }^{125}$ - then, contradictions and inconsistencies aside and certain intellectual tools at hand, one will adopt a morally robust, internal attitude with respect to law. On the other hand, if on either ground one finds law fundamentally wanting, if one encounters law as productive of diseased relations or of repressed or deformed personalities, then consistency again assumed, one will adopt an external attitude regarding law. ${ }^{126}$ This genealogy of the present situation is useful not only for its organizational and descriptive capabilities, to which I'll turn shortly, but also and more critically, for the consequences of belief which it discloses.

The internal and the external are the ways and means of our encountering, at the most fundamental of levels, all standing cultural institutions. Our concern is law, but the consequences which we will now briefly explore remain the same whatever institution, be it literature or music or art or university, is at play. ${ }^{127}$ To encounter an institution positively morally and ethically is to experience it as, and to declare it to be, a source of solace and a cause for hope. Whatever its present imperfections - and often, ${ }^{128}$ the institution's instruction and vocabulary, its ideas and ideals, alone make these discernable - the institution becomes for us an achievement and point of departure upon which our present practices and our future aspirations may be based. To borrow from Wittgenstein, the institution in these ways and senses becomes for us "a form of life," ${ }^{129}$ a place in which and a practice by which, in part at least, ${ }^{130}$ we define ourselves and our relations with others.

Encountering an institution negatively has very different consequences. To declare the institution a cause of somehow bad persons or relations is not merely to appraise it as imperfect, but rather to name it as morally and ethically corrupt and repugnant, and as it presently stands at least, ${ }^{131}$ as irredeemable. The experience of this encounter

Ibid.

As used here, morality has to do with what we ought to do regarding others and ethics with what we ought to be as persons.

The etiology of these appraisals - the ways and means of encountering any standing cultural institution as a source of dread or solace - is a metatheoretical matter which must remain beyond the reach of this paper. About which, see supra note 8.

Since law has so much to do with the nature of other institutions - and not just with the obvious ones like family, property, and religion - the encounter with law, especially by those whose lot is its custodianship, may well be considered central to the whole of cultural life.

Where this is not the case, it will be the ideals and ideas of some other institution which provide the meter.

See L. Wittgenstein, Philosophical Investigations, trans. G.E.M. Anscombe (Oxford: Blackwell, 1958) at $174 \& 226$ and paras. $19,23,241$.

In part, because it is our happy lot to be simultaneously located in numerous cultural settings. And of course, we may encounter some standing institutions positively and others negatively. How these judgments themselves relate, how a positive encounter with one institution may predispose attitudes towards other institutions, is as well a matter of much metatheoretical interest.

It appears to me that three judgments are possible with respect to institutional malaise: that the institution's ideas, ideals, and practices are in whole or in part unacceptable on either moral or ethical grounds; that the institution's staff is somehow failing its otherwise broadly acceptable ideals; or that its malaise is somehow a result of both, of some unacceptable practices and of a 
is a dread which instructs us to decline the way of life the institution offers and to take an outsider's attitude with respect to it. ${ }^{132}$ But matters do not end there, since the issue then becomes what to do instead. And it it at this juncture that the paradox of the outsider which is central to our story becomes disclosed. As we've already seen in the case of the realists, ${ }^{133}$ upon refusing an institution's way of life, one is put to the task of constructing an "otherwise." This burden can, of course, be avoided by declaring that the interests of concern to the institution may "whither away" without loss to the human situation. ${ }^{134}$ Though this shirking of responsibility by fiat too leads to paradox, ${ }^{135}$ what must concern us here is what follows on any attempt at reconstruction.

Suppose then we reject an institution, yet think its concerns, as Llewellyn did of law, ${ }^{136}$ important to human life and flourishing. How then are we to shoulder the burden of reconstruction? Though I cannot defend the view at all fully here, I want to propose that that burden can be neither discharged nor honoured, and that having declared the institution morally and ethically depraved, we are instead condemned to an empty utopianism regarding those interests. This is so even if we do not, as some do, reject the whole cloth of our institutional inheritance. ${ }^{137}$ For on rejecting their institutional practice and form, we are forbidding ourselves - however much we may value the interests at stake - the only tools possible for reconstruction. Which is to say, since a philosophy of the future is not possible de novo, in discarding the past, we prohibit ourselves a programme with respect to the future and confine ourselves instead to a morally and ethically sterile wistfulness. This is the outsider's paradox to which I referred, at once the desire to transcend the past and the inability to do anything at all about the future.

significant number of unfaithful staff. I will shortly diagnose the present crisis of faith in law with reference to the second judgment.

See M. Albert et al., Liberating Theory (Boston: South End Press, 1986) at iii where this dread is put well by Lydia Sargent: "I am haunted," she says, "by the fear that I will live out my life as a witness to the continued existence of what I hate, without ever seeing the fruits of a hoped-for revolution." Regarding the nature of the longing which Sargent is expressing, see infra notes 135 and 137 and accompanying text.

See supra notes 62-64 and accompanying text.

This, famously, is the classical marxist solution to law. Regarding which, see H. Collins, Marxism and Law (Oxford: Oxford University Press, 1982) at 100-115. For a contrary view by a marxist which takes liberal law to be a necessary threshold for a fully human future, see E.P. Thompson, Whigs and Hunters: The Origin of the Black Act (London: Allen Lane, 1975) at 258-66.

This is so because one then requires some meter for assessing which parts of our cultural legacy are expendable and which are not and because the revelation of some highest, independent and unimpeachable order aside, such a meter would have to depend on some part of that legacy itself. See supra note 2 and accompanying text.

Most marxists and some anarchists and feminists so do. Regarding the latter, see A. Dworkin, Our Blood: Prophecies and Discourses on Sexual Politics (New York: Perigee, 1976) at 48 where "revolutionary work" is defined as follows:

We must destroy the very structure of culture as we know it, its art, its churches, its laws; we must eradicate from consciousness and memory all the images, institutions, and structural mental sets that turn men into rapists by definition and women into victims by definition.

For a philosophical reflection on the nature of this rejection, see B. Yack, The Longing for Total Revolution: Philosophic Sources of Social Discontent from Rousseau to Marx and Nietzsche (Princeton: Princeton University Press, 1986). 
It is just this paradox which so starkly contrasts the moralities of engagement which the internal and external points of view define. While the insider hopes for betterment, the outsider longs for the uncharacterizable possibilities of an undisclosed and unconnected future. While the insider is possessed of a programme bred of criticism, the outsider is consumed by a corrosive cynicism about the whole of present practice. Where the insider discovers opportunities in institutional practices and languages, the outsider sees only guise and cover for the machinations of condemnable oppression and repression. The temper of these engagements not only organize and describe the present theoretical situation in law, they point as well to the fundamental dangers to which law is presently so terrifyingly vulnerable.

Putting aside the curious patch which continues, especially in Canada, ${ }^{138}$ to be claimed by unrepentant and theoretically uninformed formalists and passing over the lament which the gradual disappearance of these remaining formalists has in some quarters caused, ${ }^{139}$ the jurisprudential terrain is now occupied by two opposing forces. ${ }^{140}$ These forces are defined, not by philosophic idiom, ${ }^{141}$ but first, by their very different deployments of the intellectual liberty purchased by the realists. ${ }^{142}$ One of these forces has spent this liberty on reaching out to kindred disciplines, especially (but not only) to political philosophy, with the purpose of constructing for law a moral and ethical raison d'etre to cure postrealist disenchantment. The intent of the second force has been in just the opposite direction. Its armies have roamed not in search of consolation, but with the aim of consolidating, radicalizing, and consummating the disenchantment of law. The forces are also, therefore, defined in terms of the different attitude each takes to law. The force which would have disenchantment spent takes an internal point of view and the other force, the force committed to the final and complete disclosure of law, an external perspective. For reasons which will become more apparent, I want to name the first force in contemporary theory "The Believers" and the second, "The Cynics."

Whatever their idiom and whatever their intellectual location - be it feminism, law and economics, queer theory, law and literature, race theory, and so on - law's believers consolidate around what can only be termed a loosely-defined liberalism.

See supra note 7. But not only in Canada: English legal scholars as well seem especially prone to the intellectual amnesia - or is it self-complacent ignorance? - which alone makes formalism a continuing option. Regarding which, see N. Duxbury, "Struggling With Legal Theory" (1993) 43 U.T.L.J. 889; and, earlier along, H.L.A. Hart, "American Jurisprudence Through English Eyes: The Nightmare and The Noble Dream" (1977) 11 Georgia L. Rev. 969.

Concerning which, see H.T. Edwards, "The Growing Disjunction Between Legal Education and the Legal Profession" (1992) 91 Mich. L. Rev. 34; M.H. Redish, "The Federal Courts, Judicial Restraint, and the Importance of Analysing Legal Doctrine" (1985) 85 Columbia L. Rev. 1378; and A.W.B. Simpson, "The Rise and Fall of the Legal Treatise: Legal Principles and the Forms of Legal Literature" (1981) 48 U. Chi. L. Rev. 632.

Since I am here dealing in what I take to be paradigmatic cases, the location of any particular theorist or group of theorists on the lay of this land might well be less than precise. to a loosely-defined liberalism and the second to a variety of antiliberalisms. 
Their liberalism is loose not only because it lacks an authoritative canon, ${ }^{143}$ but more importantly because believers share a certain constellation of values. Believers think our law critical to human flourishing. ${ }^{144}$ They believe that law is significantly more than a regime of rules and that it consists instead of an always open practice concerning rights. They conceive of rights as a public morality about equal treatment and therefore as also about what has and has not to be tolerated by persons at the hands both of others and of the state. Believers are committed to moral independence and to preserving, through law's purchase of autonomy, the authenticity of individual persons, i.e. their ability to formulate and pursue their own visions of themselves.

Cynics too share much, but they no longer consolidate around any one political position, however loosely defined. ${ }^{145}$ What they instead share are a generally poorly articulated and researched antiliberalism ${ }^{146}$ and a churlishness which oftentimes verges on infantilism. ${ }^{147}$ Whatever their idiom and location, first and foremost, law's cynics are antiliberals. They are this not only because their common enemy is liberal thought and practice, but also because they share certain attitudes and beliefs. Their core attitude is cultural: they take history, at least since the Enlightenment, ${ }^{148}$ to be "one vast mistake,"149 which has culminated in an horrific present, "the universal disintegration of society into atomized individuals - selfish, calculating, materialistic,

So, for instance, allegiance to sophisticated, political philosophical liberalism of the sort on offer by, say, Dworkin, is not at all necessary.

Or more precisely put, they think critical those of its practices which they appraise as principled.

At one point - before the tide became a deluge - just the opposite was the case. In those less prolix times, the outsider's antiliberalism invariably took marxist or socialist form politically.

For present purposes, I mean "antiliberalism" to capture only nonmarxist critics of liberalism. Though marxism too can be thought an antiliberalism - as it can be thought an attempt to complete and perfect liberal accomplishments - it is very different in tone and temper from the host of antiliberalisms which presently occupy the legal academy. Since, in consequence, marxism or for that matter, socialism, only very rarely motivates contemporary legal antiliberalism, my excluding the traditional left in this fashion may perhaps be justified on grounds other than the constraints of space and purpose. Regarding the liberal values which on some readings, reside in marxism, see Holmes, supra note 115 at 1-7; and M. Berman, All That ls Solid Melts Into Air: The Experience of Modernity (New York: Penguin, 1988) at c. II.

See e.g. A.D. Freeman \& J.H. Schlegel, "Sex, Power and Silliness: An Essay on Ackerman's Reconstructing American Law" (1985) 6 Cardoza L. Rev. 847; P. Gabel \& D. Kennedy, "Roll Over Beethoven" (1984) 36 Stan. L. Rev. 1; M.G. Kelman, "Trashing" (1984) 36 Stan. L. Rev. 293; and, for a Canadian contribution, A.C. Hutchinson, "Indiana Dworkin and Law's Empire" in A.C. Hutchinson, Dwelling on the Threshold: Critical Essays on Modern Legal Thought (Toronto: Carswell, 1988) at 57.

Some, of course, condemn the whole of human history. Nonliberal feminists of the radical sort typically do so. See e.g. A. Dworkin, supra note 135 . Others date the mistake from the decline or destruction of an earlier, woman-centred culture: see e.g. R.T. Eisler, The Chalice and the Blade (Cambridge, MA: Harper \& Row, 1987). 
each at war with the rest." ${ }^{150}$ However they analyze the reproduction of this present, ${ }^{151}$ universally they name liberal theory and practice as the culprit.

In the legal academy, liberalism is convicted on grounds of two always poorly articulated beliefs which after the trial is complete, uniformly produce a naive millenarianism. We cannot here dwell on these beliefs. Several summary points will have to suffice for our story. First, in much of the academy, perspectivism and communalism have become the unexamined points of departure for legal scholarship and teaching. ${ }^{152}$ Second, because they constitute the view that we are, each of us, trapped in the happenchance of our cultural circumstances, ${ }^{153}$ together these beliefs constitute a denial of truth and a concession, if not a commitment, to a culturallydefined decisionism. ${ }^{154}$ Third, because liberalism has been accused and found guilty by means of these very beliefs, this decisionism is never thought by its devotees to have the levelling effect one would otherwise think appropriate to it. ${ }^{155}$ Instead, since through its universalist claims ${ }^{156}$ and its simultaneously atomizing, ${ }^{157}$ exclusionary, ${ }^{158}$ and homogenizing ${ }^{159}$ effects, liberalism is the culprit in the production of diseased societies and personalities and since liberalism is a distinctively Western cultural position, by some unrevealed logic, Western culture becomes morally and ethically subordinate and inferior to other, allegedly more communal and particularist cultures. ${ }^{160}$ This unaccounted and unaccountable turn to nativism - which when, as

Ibid. at 6. Nonliberal feminists and queer theorists would add to "atomized" the adjectives "male supremacist" and "heterosexist," and critical race theorists, "imperialistic."

(s) Some nonliberal feminists - Andrea Dworkin and Catharine MacKinnon, for instance - take pornography to be the linchpin of male supremacist politics and society. See A. Dworkin, supra note 135; A. Dworkin, Pornography: Men Possessing Women (New York: Dutton, 1989); and C. MacKinnon, Toward a Feminist Theory of the State (Cambridge, MA: Harvard University Press, 1989).

This absence of reflection is so complete that the perspectivist and communalist foundations of much scholarly practice fail the most rudimentary requirements of logic. Relativism of this sort or any other sort contradicts itself when it seeks to preserve any proposition from mere point of view status. The contradiction here resides in declaring cultural relativism itself to be a transcultural truth.

These circumstances are variously defined along racial, sexual, and nationalist grounds. Apposite to the cultural direction of all of this, seldom any longer does class play a leading role. Regarding decisionism, see supra notes 64 and 65 and accompanying text.

13s See S.P. Mohanty, "Us and Them: On the Philosophical Bases of Political Criticism" (1989) 2 Yale J. Criticism 1. The levelling, as Mohanty points out, should be both epistemic and moral; that is, not only should we be unable either to communicate with other cultures or compare them one to the other, as a moral matter, we should not care at all about them.

For a recent collection of essays about universalism in political theory, see (1995) 7 Differences $1-253$.

For a rejoinder to feminist claims along these lines, see L.C. McClain, "'Atomistic Man' Revisited: Liberalism, Connection, and Feminist Jurisprudence" (1992) 65 S. Calif. L. Rev. 1171. See e.g. U.S. Mehta, "Liberal Strategies of Exclusion" (1990) 18 Politics \& Society 427. 7 Theory, Culture, \& Society 5. principles, see E.W. Said, Culture and Imperialism (New York: Knoff, 1993). 
here, it is made by Westerners, constitutes as well a turn to a very peculiar selfloathing ${ }^{161}$ - takes final form in the revolutionary millenarianism which presently abounds in the legal academy. Possessed with "a burning sense of mission" ${ }^{162}$ born of their certain belief in perspectivism and communalism, these scholars abandon the detested, liberal present in anticipation of an undisclosable future in which, somehow, all will be made full. ${ }^{163}$ Because, however, they have thereby forsaken the only tools available for reflecting about and managing the future and since, in consequence, the ways and means of arriving at that blissful future must for them remain a mystery, ${ }^{164}$ they have set themselves another task with which to be occupied while they "dwell on the threshold." 165

The task which legal outsiders have taken for themselves is to disclose, through their scholarship and their teaching, law's pernicious pretences. This they do by "trashing"166 both the project of liberal law and the work of what they term "mainstream" legal scholars. ${ }^{167}$ Trashing is the churlishness which I earlier claimed to be the second characteristic of law's cynics. Now it is possible to explain this surliness, and the "assaultive politics" 168 it compels, as a competitive strategy for hearts and minds deployed by newer paradigms contesting the old. ${ }^{169}$ But this is to forgive "the politics of moral attack" which ensues as a temporary, if necessary, moral failing. ${ }^{170}$ In my view, to treat the matter in such a fashion, as a matter concerning either civility or strategy, is either to dismiss or to discount its much more fundamental importance. ${ }^{171}$ Instead, I want now to argue that the philosophy, project and programme of law's cynics places law in a position where its very survival as a moral undertaking is threatened.

A self-loathing unburdened, I should note, by any sense of irony which would follow from recognizing that revolution and utopianism are themselves distinctively Western impulses. See A. Touraine, "The Idea of Revolution" (1990) 7 Theory, Culture \& Society 121; and K. Kumar, Utopianism (Minneaplois: U. Minn. P., 1991).

See Holmes, supra note 115 at 7.

Iris Marion Young's work is an exemplary expression of all of this. See especially her widely influential M. Young, Justice and the Politics of Difference (Princeton: Princeton University Press, 1990).

Unlike most contemporary outsiders, traditional marxist legal scholars provide a map, however smudgy, to the future.

I take this turn of phrase, with regrets to Van Morrison, from Hutchinson, supra note 147. Regarding which, also see N. Duxbury, "Deconstruction, History, and the Uses of Legal Theory" (1990) 41 N. Ireland L. Rev. 167.

See Kelman, supra note 146. See also Gordon, "Law and Ideology" (1988) 3(1) Tikkan 14, at 17: "demolition rhetorics."Though Kelman coined this term to describe the intentions of critical legal scholars, in my view, it aptly captures the intentions of a whole host of antiliberal legal academics. See e.g. Minda, supra note 6.

See A. Bickle, The Morality of Consent (New Haven, Conn.: Yale University Press, 1975) at 123. This is the view taken, for instance, by Minda, see supra note 4.

Ibid.

Though each has been reviled for so doing - and by the trashers themselves no less - Paul Carrington and Owen Fiss have both attempted to uncover this deeper importance. See P.D. Carrington, "Of Law and the River" (1984) 34 J. Legal Ed. 222; and O.M. Fiss, "The Death of the Law?" (1986) 72 Comell L. Rev. 1. 
That many legal academics are outsiders and cynics, that they are committed to a host of antiliberalisms, ${ }^{172}$ that they take the traducement of law as properly their scholarly and teaching project and practice, these matters make a grand and fundamental difference just because, more than anything else, the life of the law depends upon the faith of its stewards. I had just this in mind when I cited Montesquieu at the beginning of this essay. Montesquieu was of the view that in the final analysis, what preserves and saves safe liberty and equality, is a love of the republic, a caring for and commitment to the institutional forms in which alone liberty and equality are made possible and can possibly flourish. More recently, Harold Berman has reiterated the indispensability of faith in law to the prospects for a human future, a future which law alone can ensure. ${ }^{173}$ Elsewhere, after naming the legal community generally and the legal academy especially as the carriers and custodians of faith, he declares that faith irretrievably lost and the project of liberal law, in consequence, as historically at its end. I will cite his case in full:

The crisis of the Western legal tradition is not merely a crisis in legal philosophy but also a crisis in law itself. Legal philosophers have always debated, and presumably always will debate, whether law is founded in reason and morality or whether it is only the will of the political ruler. It is not necessary to resolve that debate in order to conclude that as a matter of historical fact the legal systems of all the nations that are heirs to the Western legal tradition have been rooted in certain beliefs or postulates: that is, the legal systems themselves have presupposed the validity of those beliefs. Today those beliefs or postulates - such as the structural integrity of law, its continuity, its religious roots, its transcendent qualities - are rapidly disappearing, not only from the minds of philosophers, not only from the minds of lawmakers, judges, lawyers, law teachers, and other members of the legal profession, but from the consciousness of the vast majority of citizens, the people as a whole; and more than that, they are disappearing from the law itself. The law is becoming more fragmented, more subjective, geared more to expediency and less to morality, concerned more with immediate consequences and less with consistency or continuity. Thus the historical soil of the Western legal tradition is being washed away in the twentieth century, and the tradition itself is threatened with collapse. ${ }^{174}$

Berman's best wish for our legal tradition is that it "will perhaps serve as a kind of ancient history, a new 'corpus juris Romani,'" from which "new forms of legal order" will seek "guidance."175 His diagnosis of the legal present thus concludes with the frail hope that the future will somehow honour the past.

172 There is no sure way, of course, to document what proportion of the academy is antiliberal. In my experience, the legal academy is composed of sleepwalkers (those, especially unthinking formalists, who are awake to law in no discernable moral sense; those who, however unconsciously, are rudimentary liberals; and those who are unread cynics), of self-servers (those who use the legal academy for economic profit and for whom moral and theoretical issues are beyond any professional point), and of cognoscenti (those, liberals and antiliberals alike, who carry literate views of law). My argument depends on the legal academy being occupied by a significant number of sleepwalkers and antiliberal cognoscenti.

174 H.J. Berman, "Religious Foundations of Law in the West: An Historical Perspective" (1983) $1 \mathrm{~J}$. of Law \& Religion 1 at $41-42$. 
Unlike Berman, I think the contest not yet lost. Like him, however, I take the crisis to be both far-reaching and every bit a matter of belief and faith. I agree too that what happens in law schools has everything to do with the final resolution of the crisis in which law now finds itself. ${ }^{176}$ While, clearly, many historical factors have contributed to the present situation, ${ }^{177}$ law schools will, nonetheless, have much to do with law's future if only because law school is where future members of the legal community learn either to love or to betray law. In my view, law schools are now producing a toosignificant number of traducers. Not only - and this has always been the case - do a great many students depart their reception into the legal community with absolutely no moral sensibility about law, many of the best and brightest leave with the learning that law is only taken seriously when it is taken cynically. This becomes their learning precisely because when the legal academy is not, in the Langdellian fashion, trivializing law as a system of rules, it most often seeks to disclose it as a guise for domination and repression. Both practices betray law. But in as much as the best-motivated are often attracted and seduced by the latter, its effects are perhaps more pernicious. In any event, since legal education is now revealed as a key protagonist in the future of our story about theory in law, I will conclude this essay with a brief reflection on the prospects for education in law in Canada especially.

\section{A TENTATIVE CONCLUSION}

Fourteen years ago, a national Consultative Group on Research and Education in Law - appointed by the Social Sciences and Humanities Research Council of Canada and chaired by Professor Harry Arthurs of Osgoode Hall Law School - declared legal education in Canada to be irredeemably fractured by the law schools' and professorate's allegiances to the profession, on the one hand, and to the academy, on the other. There was, it was claimed, an irreconcilable asymmetry between the obligation to prepare students for the profession and the obligation to excite in them a scholarly interest in the law. Disciplined reflection about law was somehow seen, then, the disconsolation of professional preparation. In its report, Law and Learning, ${ }^{178}$ the Consultative Group made good this understanding by recommending splitting legal education into two separate streams - a scholarly stream for students with intellectual and theoretical ambitions and abilities, and a professional stream for students with more prosaic ambitions and capacities. ${ }^{179}$

Though it is unquestionably the case that the academization of the legal academy since the realists has had much to do with the course of events leading to the

But, of course, law school is not solely responsible. When after school, they are received into articles, the profession is most often revealed to them as a morally and spiritually empty cartel which uses the pretence of their further socialization as a means for profit.

For Berman's view of these, see supra note 174 at $42-43$. He fails to mention what I take to be the single most important factor, however unconsciously felt its impact, in the erosion of confidence in Western institutions including law: the Holocaust. 
problematic present, ${ }^{180}$ no one, I think, would any longer reasonably suggest that the solution is to bifurcate legal education along the lines suggested by the Consultative Group. This is so because it is now everywhere ${ }^{181}$ conceded that legal theory and legal education are on the most intimate of terms. ${ }^{182}$ Since legal education has always been thought to have everything, in turn, to do with the nature and quality of professional practice, it now also generally admitted that the future of law will depend, in some measure at least, on the theoretical underpinnings of legal education. So to ask "whither legal theory?" is very much to ask "whither law?"

That the future of law, in these senses, depends on the theoretical stories legal academics tell future practitioners, I want to suggest, raises certain ethical and moral demands. The moral obligation of law schools ${ }^{183}$ is to imbue in students a belief, a faith, in law. It is their burden, that is, to make of students the kind of persons morally and ethically fit for a life in law, a life of service to life's terrifying dependence on law. To meet this obligation, legal academics must themselves be persons of a certain sort. They themselves must be not only academically literate in law, not merely theoretically informed and read, they must as well carry and communicate a moral sensibility about law, they must profess their faith in law. This ethical demand, it turns out, presents the rub.

As we have seen, the academization of the legal academy has, in significant measure, resulted not in the discharge of these demands, but in their abandonment. More fundamentally yet, "the rise of academic illiberalism," 184 which we have tracked into the present, has led as well to a wholesale decline of guilt among legal academics about their infidelity to law's moral and ethical demands. Typically, they wrap themselves instead in the sacred shroud of academic freedom and disdain any obligations their

This entire essay is devoted, as much as anything, to proving just that point. For Carrington's view on the course of these events, see "Butterfly Effects," supra note 7 at 789-92; and "Hail! Langdell!" at 759-60.

181 Everywhere, but certainly not by everyone, since the legal academy - perhaps because unlike other disciplines, it requires no set qualifications for professorship - continues to be occupied by those whom I earlier termed sleepwalkers and self-servers: see supra note 172.

See e.g. Sunstein, "On Legal Theory and Legal Practice" in I. Shapiro \& J.W. DeCew, eds., Nomos XXXVII: Theory and Practice (New York: N.Y.U.P., 1995) at 267; A. Thompson, "Foreword: Critical Approaches to Law. Who Needs Legal Theory?" in I. Grigg-Spall \& P. Ireland, eds., The Critical Lawyers Handbook (London: Pluto Press, 1992) at 2; and A. Singer, "Should Lawyers Care About Philosophy?" [1989] Duke L.J. 1752. For the gadfly view that theory is superfluous to law - its "lard" - see S. Fish, Doing What Comes Naturally: Change, Rhetoric, and the Practice of Theory in Literary and Legal Studies (Durham, NC: Duke University Press, 1989). For views of which, see W.C. Twining, "What are Law Schools For?" in W.L. Twining, Blackstone's Tower: The English Law School (London: Sweet \& Maxwell, 1994) at 49; T. Sandalow, "The Moral Responsibility of Law Schools" (1984) 34 J. Leg. Ed. 163; R.A. Wasserstrom, "Legal Education and the Good Lawyer" (1984) 34 J. Leg. Ed. 155; and L. Fuller, "On Legal Education" in The Principles of Social Order, supra note 105 at 271.

184 I am citing with purpose Konrad Jarausch's description of another period from which, unhappily, too few in the legal academy have sought instruction. See K. Jarausch, The Unfree Professions: German Lawyers, Teachers, and Engineers, 1900-1950 (Oxford: Oxford University Press, 1990) at viii. 
situation in a professional school might otherwise present. ${ }^{185}$ But this will not do either as an excuse for them or as an explanation for us.

Singer offers a more productive and certainly more intriguing view of the matter. In his judgment, legal theory and justice stand in an always "rocky relationship." ${ }^{186}$ This is so, he claims, because while we may wish theory "to define and support just social institutions," theory is an unruly horse which will often take the direction of undermining and corroding those institutions. ${ }^{187}$ If this is so - and I so take it then the situation in the legal academy is not a matter of academic freedom, but much more fundamentally, a matter of the necessity of theorizing, on the one hand, and of the institutional dangers of doing so, on the other.

Since there is no way out of this state of affairs, no climax is possible to our story. But this does not at all mean that "post-Realist legal theory has about run its course headlong into a dead end."188 Since legal theory and legal education are now forever bedded, barring the catastrophic, this tale of law's fate will continue yet. And as regards the future which will somehow come to pass, perhaps the best for which we can hope is that legal academics come to their tasks with wide learning and deep humility. As I hope I have convinced, so much depends on their doing so. 